\title{
PENGARUH MOTIVASI DAN BUDAYA ORGANISASI TERHADAP PRODUKTIFITAS KERJA KARYAWAN ( STUDI KASUS DI PT BOOGI AVINDO, BOGOR)
}

\author{
Arif Prayogo \\ Politeknik LP3I Jakarta \\ Ario0803@yahoo.com
}

\begin{abstract}
Abstrak. Penelitian ini diangkat dari penelitian tesis yang bertujuan untuk menganalisis seberapa besar Pengaruh Motivasi dan Budaya Organisasi terhadap Produktifitas kerja Karyawan ( Studi kasus di PT Boogi Avindo, Bogor). Penelitian tersebut didasarkan atas fenomena yang menunjukkan kecenderungan menurunnya produktifitas kerja karyawan yang salah satu diantaranya disebabkan karena rendahnya motivasi kerja karyawan serta lemahnya budaya kerja perusahaan Metode pengambilan sampel yang digunakan adalah Simple Random Sampling. Sampel dalam penelitian ini mengikuti rumus Slovin, atau sebanyak 35 orang karyawan.

Data-data yang telah memenuhi uji validitas dan uji reliabilitas selanjutnya diolah sehingga menghasilkan persamaan regresi $0.242+0.286 \mathrm{X} 1+0.699 \mathrm{X} 2$, dimana Y adalah variabel Produktivitas Kerja Karyawan, X1 adalah variabel Motivasi dan X2 adalah variabel Budaya Organisasi. Pengujian hipotesis menggunakan uji t menunjukkan bahwa masing-masing variabel independen yang diteliti terbukti secara signifikan berpengaruh secara parsial terhadap variabel dependen Produktivitas Kerja Karyawan. Motivasi secara parsial berpengaruh positif terhadap Produktifitas Kerja yang ditunjukkan oleh nilai $\mathrm{r}$ sebesar 0.815 yang berarti hubungan diantara keduanya kuat. Budaya Organisasi secara parsial berpengaruh positif terhadap Produktifitas Kerja ditunjukkan oleh nilai $\mathrm{r}$ sebesar 0,747 yang berarti hubungan diantara keduanya kuat. Secara simultan variabel Motivasi dan Budaya Organisasi memiliki pengaruh yang signifikan terhadap Produktifitas Kerja yang ditunjukkan oleh nilai $\mathrm{r}$ sebesar 0,776 yang berarti hubungan diantara keduanya sangat kuat. Sedangkan nilai koefisien determinasi (R2) adalah sebesar 0,602 yang berarti bahwa Motivasi bersama sama dengan Budaya Organisasi dapat menerangkan variabel Produktifitas Kerja sebesar 60,2 \% sedangkan sisanya sebesar 39,8\% diterangkan oleh variabel lain.
\end{abstract}

Kata Kunci : Motivasi, Budaya Organisasi dan Produktivitas Kerja, PT Boogi Avindo, Regresi Linier Berganda

Abstract. This study was taken from the thesis research aims to analyze how much Influence Motivation and Cultural Organization on labor productivity Employees (Case Study in PT Boogi Avindo, Bogor). The study is based on the phenomenon, which showed a decrease in employee productivity, one of them due to low employee motivation, and poor corporate culture

The sampling method used is simple random sampling. The sample in this study followed the formula Slovin, or as many as 35 employees.

Data that has met the test of validity and reliability further processed to produce a regression equation $0.242+0286 X 1+0.699 X 2$, where $Y$ is the variable Employee Productivity, Motivation $X 1$ and $X 2$ are the variables are variables Organizational Culture. Hypothesis testing using $t$ test showed that each of the independent variables studied was shown to significantly affect the dependent variable partially on Employee Productivity. Motivation partially positive effect on Work Productivity indicated by the $r$ value of 0815 which means a strong relationship between them. Organizational culture is partially positive effect on Work Productivity indicated by the $r$ value of 0.747 , which means a strong relationship between them. Motivational variables simultaneously and Cultural Organization has a significant influence on Work Productivity indicated by the $r$ value of 0.776 which means the relationship between them is very strong. While the value of the coefficient of determination (R2) is equal to 0.602, which means that motivation together with Cultural Organization may explain the variable Work Productivity by 60, 2\%, while the remaining $39.8 \%$ is explained by other variables. 
Keywords: Motivation, Organizational Culture and Work Productivity, PT Boogi Avindo, Multiple Linear Regression

Produktifitas kerja mengandung pengertian yang berkenaan dengan konsep ekonomis, filosofis dan sistem. Sebagai konsep ekonomis, produktivitas berkenaan dengan usaha atau kegiatan manusia untuk menghasilkan barang atau jasa yang berguna untuk memenuhi kebutuhan manusia dan masyarakat pada umumnya.

Sebagai konsep filosofis, produktivitas mengandung pandangan hidup dan sikap mental yang selalu berusaha untuk meningkatkan mutu kehidupan dimana keadaan hari ini harus lebih baik dari hari kemarin, dan mutu kehidupan hari esok harus lebih baik dari hari ini. Hal inilah yang memberi dorongan untuk berusaha dan mengembangkan diri. Sedangkan konsep sistem, memberikan pedoman pemikiran bahwa pencapaian suatu tujuan harus ada kerja sama atau keterpaduan dari unsur-unsur yang relevan sebagai sistem.

Dapat dikatakan bahwa produktivitas adalah perbandingan antara hasil dari suatu pekerjaan karyawan dengan pengorbanan yang telah dikeluarkan. Produktivitas adalah kemampuan memperoleh manfaat yang sebesarbesarnya dari sarana dan prasarana yang tersedia dengan menghasilkan output yang optimal bahkan kalau mungkin yang maksimal." Secara umum produktivitas diartikan sebagai hubungan antara hasil nyata maupun fisik (barang-barang atau jasa) dengan masuknya yang sebenarnya. Produktivitas juga diartikan sebagai tingkatan efisiensi dalam memproduksi barang-barang atau jasa-jasa. Produktivitas juga diartikan sebagai perbandingan ukuran harga bagi masukan dan hasil. Disamping itu produktifitas kerja juga bisa diartikan sebagai perbedaan antara kumpulan jumlah pengeluaran dan masukan yang dinyatakan dalam satuan-satuan (unit) umum.

Berkaitan dengan hal tersebut, berdasarkan hasil observasi di lokasi penelitian, penulis mengetahui bahwa produktifitas kerja karyawan masih rendah. Hal tersebut terlihat dari sering tidak tercapainya target produksi sesuai dengan rencana produksi yang telah ditetapkan. Tidak tercapainya target produksi tersebut sebagai akibat dari masih lemahnya

semangat dan motifasi kerja karyawan di satu sisi, serta masih lemahnya budaya organisasi perusahaan di sisi yang lain.

Adapun penurunan produktifitas kerja karyawan PT Boogy Avindo tersebut tercermin dari beberapa fenomena kasus sebagai berikut: 1. Masih sering terjadi para karyawan datang tidak tepat waktu karena alasan macet, sehingga catatan kartu absen seringkali banyak yang merah; 2. Hasil kerja cenderung semakin menurun, tercermin dari laporan bulanan yang menunjukkan pencapaian perolehan hasil kerja cenderung menurun; 3. Waktu masuk setelah jam istrirahat seringkali terlambat; 4. Kinerja kekompakkan team cenderung menurun, yang dicerminkan oleh koordinasi yang kurang, sehingga kinerja tidak maksimal; 5. Masih sering terjadi karyawan yang tidak masuk kerja karena alasan sakit, izin atau alpa; 6. Kualitas hasil kerja cenderung menurun, yang terlihat dari kualitas produk yang belum maksimal, selalu terdapat kekurangan di sana-sini.

Dari sekian banyak factor penyebab menurunnya produktifitas kerja karyawan, penulis menduga bahwa motivasi dan budaya kerja karyawan merupakan faktor utama yang mempengaruhi produktifitas kerja karyawan dalam suatu perusahaan.

Berdasarkan hal itulah, maka penulis tertarik untuk meneliti Pengaruh Motivasi dan Budaya Kerja terhadap Produktifitas kerja Karyawan ( Studi kasus di PT Boogi Avindo, Bogor)

Motivasi

Motivasi berasal dari kata motive. Motive berasal dari kata "motion" yang berarti "gerakan". Menurut Vroom seperti yang dikutip Faizah dan Lalu Muchsin Effendi :

"Motivasi mengacu kepada suatu proses mempengaruhi pilihan-pilihan individu terhadap bentuk-bentuk kegiatan yang dikehendaki. Istilah motivasi ini mencakup sejumlah konsep seperti dorongan (drive), kebutuhan (need), rangsangan, ganjaran dan sebagainya. Jadi dapat dijelaskan bahwa motif merupakan dorongan yang timbul dalam diri seseorang yang menyebabkan orang tersebut mau bertindak 
Arif Proyogo, Pengaruh Motivasi Dan Budaya Organisasi ...

untuk melakukan sesuatu. Sedangkan motivasi adalah pendorong kepada suatu usaha yang disadari untuk mempengaruhi tingkah laku seseorang agar ia tergerak untuk melakukan sesuatu sehingga mencapai hasil atau tujuan tertentu. Jadi, motif cenderung instrinsik sedangkan motivasi cenderung ekstrinsik. Atau dapat dikatakan motivasi adalah pendorong munculnya motif".

Dari uraian di atas terlihat jelas bahwa motivasi dipengaruhi oleh pilihan yang muncul dari dalam sebagai pendorong, sehingga seseorang bertindak sesuai kehendaknya.Motivasi sendiri erdiri dari dua kata yang mempunyai pengertian sendirisendiri. Namun kedua pengertian tersebut membentuk satu pengertian pembahasan. Untuk lebih jelasnya penulis menguraikan satu persatu diantara keduanya. Motivasi berasal dari bahasa Inggris "motive" yang diambil dari kata asalnya motion yang berarti "gerak atau sesuatu yang bergerak". Sedangkan menurut Sardiman, motive diartikan sebagai daya dan upaya yang mendorong seseorang untuk melakukan sesuatu. Motif dapat di katakan sebagai daya penggerak dari dalam dan di dalam subyek untuk melakukan aktivitas-aktivitas tertentu demi mencapai suatu tujuan. Bahkan motif dapat diartikan sebagai suatu kondisi Intern (kesiapsiagaan). Berawal dari kata "motif" itu, maka motivasi dapat diartikan sebagai daya penggerak yang telah menjadi aktif. Motif menjadi aktif pada saat-saat tertentu, terutama bila kebutuhan untuk mencapai tujuan sangat dirasakan/mendesak.

Menurut Maslow, dimensi dan indikator motivasi kerja adalah sebagai berikut: 1 . Diminesi Fisiologis, yang terdiri dari indikator, kondisi kerja, gaji, penyediaan ruang kerja, penyediaan sarana kerja, dan fasilitas kerja; 2. Dimensi Keamanan, yang terdiri dari indikator Jaminan keamanan lingkungan kerja, dukungan pengamanan dalam pelaksanaan kerja dan perlindungan terhadap resiko pekerjaan; 3 . Dimensi Penghargaan, yang terdiri dari indikator penghargaan kerja, promosi Jabatan, dan penghargaan masyarakat; 4. Dimensi Berkelompok, yang terdiri dari indikator hubungan antar sesama karyawan, dukungan sesama karyawan dan hubungan dengan lembaga; 5. Dimensi Aktualisasi Diri, yang terdiri dari indikator aktualisasi identitas diri, ktualisasi profesionalitas masyarakat dan aktualisasi akuntabilitas masyarakat.

\section{Budaya Organisasi}

Menurut Robbins (1999), budaya organisasi adalah sistem nilai bersama dalam suatu organisasi yang menentukan tingkat bagaimana para karyawan melakukan kegiatan untuk mencapai tujuan organisasi. Budaya organisasi juga didefinisikan sebagai suatu nilainilai yang mempedomani sumber daya manusia dalam menghadapi permasalahan eksternal dan usaha memahami nilai- nilai yang ada serta mengerti bagaimana mereka harus bertindak dan bertingkah laku (Susanto, 1997). Semua sumber daya manusia harus dapat memahami dengan benar budaya organisasinya, karena pemahaman ini sangat berkaitan dengan setiap langkah ataupun kegiatan yang dilakukan, baik perencanaan yang bersifat strategis dan taktikal maupun kegiatan impleentasi perencanaan, dimana setiap kegiatan tersebut harus berdasar pada budaya organisasi.

Jadi menurut teori di atas, budaya organisasi adalah sebuah sistem makna bersama yang dianut oleh para anggota yang membedakan suatu organisasi dari organisasiorganisasi lainnya. Sistem makna bersama ini adalah sekumpulan karakteristik kunci yang dijunjung tinggi oleh organisasi.

Menurut Prabundu (2004 : 2-7), dimensi dan indikator Budaya Organisasi yaitu sebagai berikut: 1. Dimensi Karakteristik primer, yang terdiri dari indikator : Inovasi, siap menghadapi resiko, orientasi orang, orientasi hasil dan tim, keagresipan dan menetapkan nilai-nilai; 2 . Dimensi Langkah Memperkuat Budaya Organisasi, yang terdiri dari indikator : melakukan pembinaan terhadap anggota, memberikan contoh teladan, membuat acara rutinitas, memberikan penilaian dan penghargaan; 3. Dimensi Sikap Kerja, yang terdiri dari indikator : sikap dalam melayani, sikap dalam melaksanakan pekerjaan, dan sikap melakukan inisiatif kerja; 4. Dimensi Tingkat keterampilan, yang terdiri dari indikator ketrampilan pencapaian tugas, ketrampilan melaksanakan program, dan ketrampilan mengevaluasi pencapaian program.

\section{Produktifitas Kerja}




\begin{abstract}
Pentingnya produktivitas kerja mencakup banyak hal, dimulai dari produktivitas tenaga kerja, produktivitas organisasi, produktivitas modal, produktivitas pemasaran, produktivitas produksi, produktivitas keuangan dan produktivitas produk. Pada tahap awal revolusi industri di negara-negara Eropah, perhatian lebih banyak tertuju pada bidang produktivitas tenaga kerja, produktivitas produksi dan produktivitas pemasaran. Sedangkan di negara Jepang, perhatian peningkatan produktivitas tertuju pada produktivitas tenaga kerja dan produktivitas organisasi, sehingga keharmonisan kepentingan buruh dan majikan dipelihara dengan baik.
\end{abstract}

Pentingnya arti produktivitas dalam meningkatkan kesejahteraan telah disadari secara universal, tidak ada jenis kegiatan manusia yang tidak mendapatkan keuntungan dari produktivitas yang ditingkatkan sebagai kekuatan untuk menghasilkan lebih banyak barang-barang maupun jasa, peningkatan produktivitas juga menghasilkan peningkatan langsung pada standar hidup yang berada dibawah kondisi distribusi yang sama dari perolehan produktivitas yang sesuai dengan masukan tenaga kerja. Sayang sekali produktivitas sering dikaitkan secara paksa, acuh tak acuh terhadap kualitas hidup dan pengaruh yang membahakan bagi lingkungan. Misalnya, nasionalisasi tidak manusiawi.

Dari sejumlah teori yang dideskripsikan untuk memperoleh dukungan teoritik penyusunan konsep operasional variabel penelitian, menurut Balai Pengembangan Produktivitas Daerah (dalam Umar, 2001: 11) menjelaskan ada enam faktor utama yang menentukan produktivitas tenaga kerja yaitu Sikap Kerja, Tingkat keterampilan, Hubungan antara tenaga kerja dan pimpinan, Manajemen produktivitas, Efisiensi tenaga kerja dan Kewiraswastaan.

Dengan pandangan ini terdapat enam dimensi yaitu : dimensi Sikap Kerja, dimensi Tingkat keterampilan, dimensi Hubungan antara lingkungan kerja, dimensi Manajemen produktivitas, dimensi Efisiensi tenaga kerja dan dimensi Kewiraswastaan maka disusun konsep operasional variabel produktivitas kerja sebagai berikut: 1. Dimensi Sikap Kerja dioperasionalkan menjadi 3 indikator penelitian yang terdiri dari indikator-indikator sikap dalam melayani, sikap dalam melaksanakan pekerjaan, dan sikap melakukan inisiatif kerja; 2. Dimensi Tingkat Ketrampilan dioperasionalkan menjadi 3 indikator penelitian yang terdiri dari indikatorindikator ketrampilan pencapaian tugas, ketrampilan melaksanakan program, dan ketrampilan mengevaluasi pencapaian program; 3. Dimensi Hubungan antara lingkungan kerja dioperasionalkan menjadi 3 indikator penelitian yang terdiri dari indikator-indikator hubungan kerja dengan pimpinan, hubungan kerja dengan antar bagian, dan hubungan kerja dengan rekan sekerja; 4. Dimensi Manajemen Produktivitas dioperasionalkan menjadi 3 indikator penelitian yang terdiri dari indikator-indikator koordinasi pekerjaan, komunikasi antar bagian, dan tanggungjawab pekerjaan; 5. Dimensi Efisiensi tenaga kerja dioperasionalkan menjadi 3 indikator penelitian yang terdiri dari indikatorindikator jumlah tenaga kerja, pemanfaatan tenaga kerja, dan pemanfaatan waktu tenaga kerja; 6. Dimensi Kewiraswastaan dioperasionalkan menjadi 3 indikator penelitian yang terdiri dari indikator-indikator kemampuan melihat potensi diri, kemampuan melihat potensi diri, dan kemampuan melihat potensi organisasi.

\section{Kerangka Pemikiran}

Adapun dalam penelitian ini kerangka konseptual diformulasikan dalam sebagai berikut: 1. Model Paradigma Hubungan antara Motivasi Kerja dan Budaya Orgamisasi dengan Produktifitas Kerja Karyawan, Berdasarkan uraian-uraian penjelasan sebelumnya, maka dapat dirumuskan kerangka pemikiran teoritis (paradigma) antara Motivasi Kerja, Budaya Organisasi dan Produktifitas Kerja adalah sebagaimana gambar berikut :

\section{Metode Penelitian :}

Jenis penelitian ini adalah kuantitatif Adapun sifat penelitian ini adalah penelitian penjelasan (explanatory), yaitu suatu penelitian yang menguraikan dan menjelaskan fenomena yang terjadi di objek penelitian. Adapun kerangka pemikiran penelitian, dapat dilihat sebagaimana digambarkan berikut ini : 


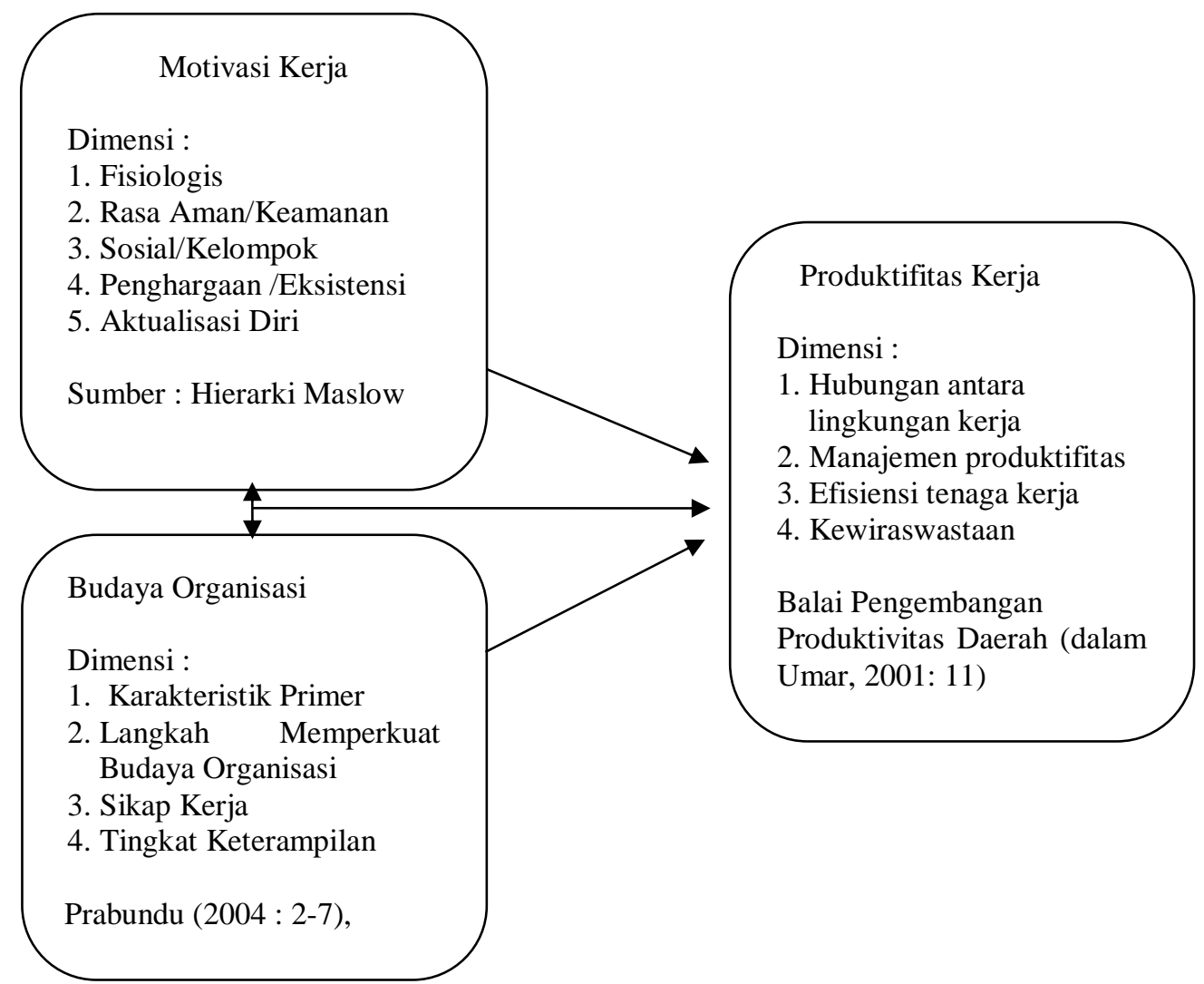

Gambar. Kerangka Pemikiran Penelitian

\section{Hipotesis Penelitian}

Hipotesis adalah dugaan sementara yang kebenarannya masih harus dilakukan pengujian (Sugiyono, 2009). Hipotesis ini dimaksudkan untuk memberi arah bagi analisis penelitian. Dalam penelitian ini, hipotesis yang digunakan adalah sebagai berikut: 1. Motivasi kerja mempunyai pengaruh yang positif dan signifikan terhadap produktifitas kerja; 2 . Budaya organisasi mempunyai pengaruh yang positif dan signifikan terhadap produktifitas kerja; 3. Motivasi kerja dan budaya organisasi mempunyai pengaruh positif dan siginifikan terhadap produktifitas kerja

\section{Operasionalisasi Variabel}

Operasionalisasi variable dari penelitian yang diangkat penulis terdiri dari Variabel Motivasi (X1) dan Budaya Organisasi (X2) sebagai variable yang memengaruhi atau disebut juga sebagai variabel penyebab, atau sering disebut sebagai variabel bebas atau independent variable (X), serta Variable Produktifitas Kerja Karyawan (Y) sebagai variabel akibat disebut variabel variabel tergantung atau dependent variable.

Dalam Operasionalisasi Variabel tersebut berisi Kisi-kisi Variabel Penelitian yang memuat deskripsi dimensi (subvariabel), setiap dimensi dirumuskan indikatornya untuk kemudian menjadi item angket (quisionery).

\section{Tabel 1 Kisi-Kisi Variabel}

\begin{tabular}{|c|c|c|c|c|}
\hline Varibel & Dimensi & Indikator & No Item & $\begin{array}{c}\text { Jumlah } \\
\text { item }\end{array}$ \\
\hline $\begin{array}{l}\text { Motivasi } \\
\text { (Hierarki } \\
\text { Maslow) }\end{array}$ & Fisiologis & $\begin{array}{ll}\text { 1. } & \text { Kondisi Kerja } \\
\text { 2. } & \text { Gaji } \\
\text { 3. } & \text { Penyediaan ruang kerja } \\
\text { 4. } & \text { Penyediaan Sarana kerja } \\
\text { 5. } & \text { Fasilitas kerja } \\
\end{array}$ & $1,2,3,4,5$ & 5 \\
\hline
\end{tabular}




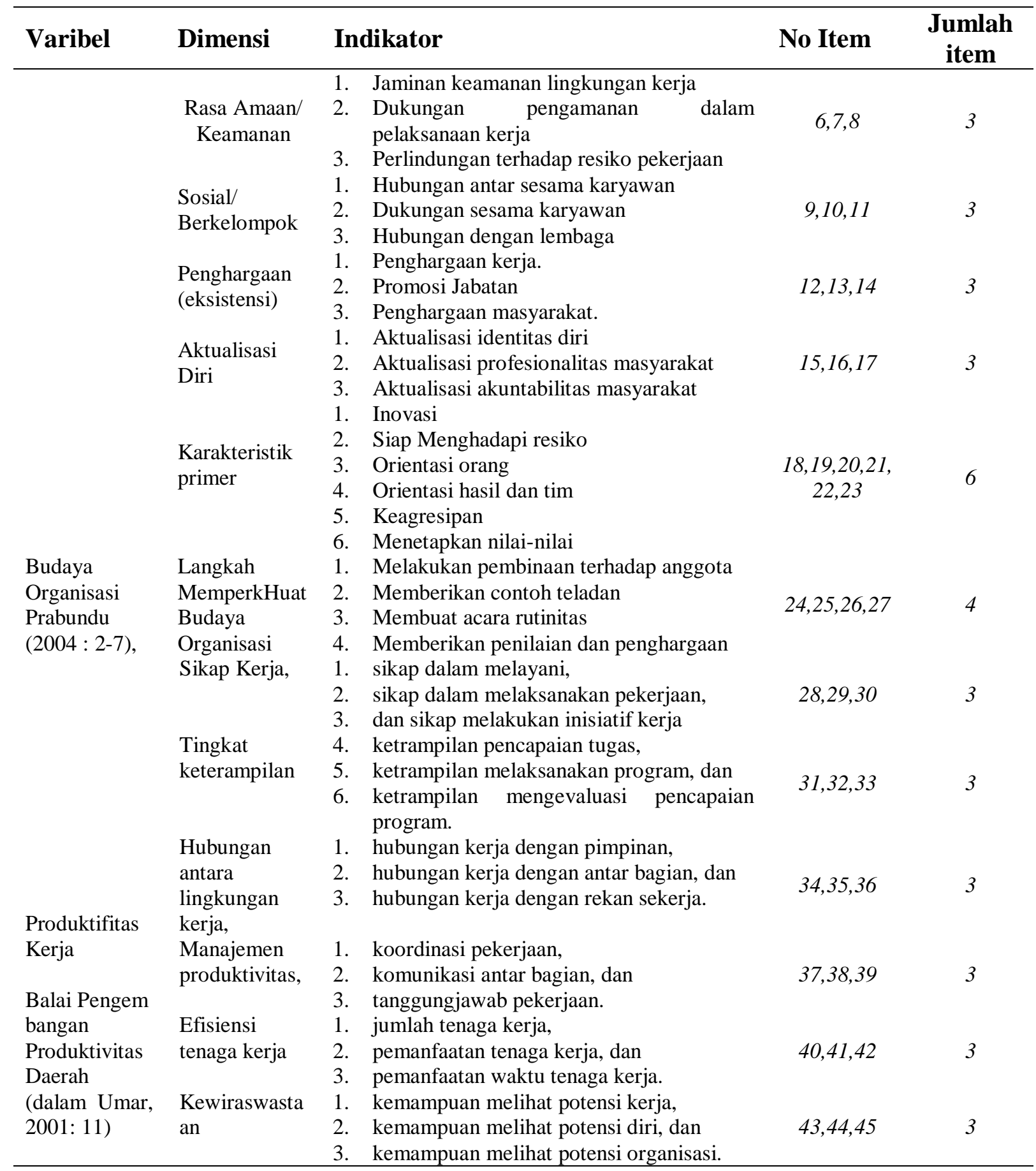

\section{Populasi dan Sampel Penelitian}

Populasi adalah keseluruhan subyek penelitian (Arikunto, 2006: 130). Dengan menetapkan populasi, ini dimaksudkan agar suatu penelitian dapat mengukur sesuatu sesuai dengan kasusnya dan tidak berlebihan dengan populasi yang diacu. Adapun jumlah populasi karyawan PT Boogi Avindo yaitu sebanyak 54 orang

\section{Sampel}

Yang dimaksud dengan sampel adalah sebagian atauwakil populasi yang diteliti (Arikunto, 2006: 131). Sesuai dengan pemahaman diatas, maka sampel dalam penelitian ini adalah sebagian atau wakil yang sudah ditentukan.

\section{Teknik pengambilan sampel}

Teknik pengambilan sampel dalam penelitian ini adalah Sampel Acak Sederhana (Simple Random Sampling). Sampel Acak 
Arif Proyogo, Pengaruh Motivasi Dan Budaya Organisasi ...

Sederhana (Simple Random Sampling) ialah sebuah sampel yang diambil sedemikian rupa sehingga tiap unit penelitian atau satuan elementer dari populasi mempunyai kesempatan yang sama untuk dipilih sebagai sampel (Singarimbun, 1995: 154).

Teknik pengambilan sampel dilakukan dengan menggunakan rumus Slovin yaitu sebagai berikut :

$$
\begin{aligned}
& \mathrm{n}=\mathrm{N} /\left(1+\mathrm{Ne}^{2}\right) \\
& \text { Dimana }: \\
& \mathrm{n}=\text { sample } \\
& \mathrm{N}=\text { Populasi } \\
& \mathrm{e}=\text { tingkat kesalahan }(0.1)
\end{aligned}
$$

Dari jumlah populasi sebanyak 54 orang, maka jumlah sample adalah :

$$
\begin{aligned}
& \mathrm{n}=54 /\left(1+54(0.1)^{2}\right) \\
& \mathrm{n}=54 /(1+54(0.01)) \\
& \mathrm{n}=54 /(1+0,54) \\
& \mathrm{n}=54 / 1,54 \\
& \mathrm{n}=35
\end{aligned}
$$

\section{Teknik Analisis Data}

Meliputi Uji kualitas data yaitu Validitas intstrumen dan Uji reliabilitas instrumen, analisis statistik deskriptif yaitu statistik untuk menganalisis data dengan cara mendeskripsikan atau menggambarkan data sebagaimana adanya tanpa membuat kesimpulan yang berlaku untuk umum atau generalisasi, uji Normalitas, Uji Multikolinieritas, Uji Autokorelasi, dan Uji Heterokedastisitas, uji analisis regresi linear berganda, uji t, uji F, ANOVA, uji koefisien korelasi dan determinasi

\section{Hasil dan Pembahasan}

\section{Hasil Penelitian}

Dari hasil penelitian dapat dideskripsikan halhal sebagai berikut :

\section{Deskripsi Obyek Penelitian}

\section{Sejarah Perusahaan}

PT Boogie Advindo adalah perusahaan swasta nasional yang didirikan pada tahun 1991 yang bergerak dibidang industri dan perdagangan peralatan dan perlengkapan kegiatan alam bebas. Bermula dari usaha pembuatan Alas kaki ( Footwear ) seperti Sandal \& Sepatu gunung sebagai produk perintis yang menjadi cikal-bakal berdirinya industri pt.Boogie Advindo. Lalu kemudian berkembang lagi ke industri garment dengan produk andalannya tas gunung, jaket dan tenda hingga akhirnya terus berkembang menjadi industri pembuatan perahu karet ( inflatable Boat ) untuk kegiatan olahraga arung jeram, SAR hingga militer sampai hari ini.

\section{Visi dan Misi}

VISI. Menjadikan Produsen peralatan outdoor sport, SAR dan Militer terdepan di Indonesia dengan mengutamakan kualitas dan pelayanan terbaik untuk memberikan manfaat berkelanjutan bagi seluruh masyarakat /stakeholder.

MISI : 1. Meningkatkan citra produk dan perusahaan dengan membangun system; 2 . yang dinamis dan profesional disertai komitmen yang kuat; 3. Memenuhi target pengadaan produk yang bersaing; 4. serta meningkatkan pelayanan dan kerjasama yang efektif; 5. Mengembangkan pasar internasional dengan memenuhi dan 6. produk dan kualitas eksport.

\section{Kapasitas Produksi per tahun}

$\square$ Produk Sandal dan sepatu pasang

$\square$ Produk tas dan asesoris 100.000 pasang

$\square$ Produk perahu karet $\quad$ : 800 unit

$\square$ Produk pelampung : 5000 unit

$\square$ Produk tenda dan perlengkapan : $\quad 100$ unit

$\square$ Produk pakaian lapangan $\quad$ : 50.000 pcs

\section{Deskripsi Responden}

Responden dalam penelitian ini adalah semua karyawan PT Boogi Avindo, Bogor. Jumlah karyawan yang dipilih sebagai responden sebanyak 54 orang dengan identitas sebagai berikut : usia dan Divisi

Usia Responden

Usia responden relative homogen dengan kisaran umur antara $18 \mathrm{~s} / \mathrm{d} 60$ tahun.

Divisi

Penggolongan responden menurut tingkat pendidikannya dikelompokkan dalam tabel 4.3 berikut ini : 
Majalah Ilmiah Ilmu Administrasi

ISSN 1411-0830

Tabel Distribusi Responden menurut Bidang Pekerjaaan

\begin{tabular}{lccc}
\hline Bidang Pekerjaaan & $\begin{array}{l}\text { Jumlah } \\
\text { Karyawan }\end{array}$ & Frekuensi & Prosentase(\%) \\
\hline Produksi & 9 & 18 & 22,61 \\
Marketing & 9 & 19 & 26,09 \\
Keuangan & 8 & 12 & 16,52 \\
SDM & 10 & 5 & 10,43 \\
Gudang & 8 & 6 & 8,70 \\
Administrasi & 10 & 10 & 15,65 \\
Jumlah & $\mathbf{5 4}$ & $\mathbf{3 5}$ & $\mathbf{1 0 0}$ \\
\hline Sumber
\end{tabular}

Sumber : Data Perusahaan 2014

\section{Uji Validitas dan Uji Reliabilitas}

\section{Uji Validitas}

Uji validitas digunakan untuk mengukur sah atau tidak sahnya suatu kuesioner. Dasar pengambilan keputusan yang digunakan adalah melakukan uji signifikasi dengan membandingkan nilai $r$ hitung dengan $r$ kritis yang nilainya 0,3 . Pengambilan keputusan uji validitas :

- Bila nilai $r$ hitung $>\mathrm{r}$ kritis, maka item pertanyaan valid

- Bila nilai $r$ hitung $<\mathrm{r}$ tkrits, maka item pertanyaan tidak valid

Pengujian validitas selengkapnya dapat dilihat pada tabel berikut ini

\section{Tabe Uji Validitas Variabel Motivasi Correlations}

\begin{tabular}{|c|c|c|}
\hline & & Tot_Ekuitas_Merk \\
\hline \multirow{4}{*}{ Tot_Motivasi } & Pearson Correlation & 1 \\
\hline & Sig. (1-tailed) & \\
\hline & $\mathrm{N}$ & 35 \\
\hline & Pearson Correlation &, $341^{* *}$ \\
\hline \multirow[t]{3}{*}{ MOTIVASI_1 } & Sig. (1-tailed) & ,000 \\
\hline & $\mathrm{N}$ & 35 \\
\hline & Pearson Correlation &, $605^{* *}$ \\
\hline \multirow[t]{3}{*}{ MOTIVASI_2 } & Sig. (1-tailed) &, 000 \\
\hline & $\mathrm{N}$ & 35 \\
\hline & Pearson Correlation &, $538^{* *}$ \\
\hline \multirow[t]{3}{*}{ MOTIVASI_3 } & Sig. (1-tailed) &, 000 \\
\hline & $\mathrm{N}$ & 35 \\
\hline & Pearson Correlation &, $597^{* *}$ \\
\hline \multirow[t]{3}{*}{ MOTIVASI_4 } & Sig. (1-tailed) & 000 \\
\hline & $\mathrm{N}$ & 35 \\
\hline & Pearson Correlation &, $656^{* *}$ \\
\hline \multirow[t]{3}{*}{ MOTIVASI_5 } & Sig. (1-tailed) &, 000 \\
\hline & $\mathrm{N}$ & 35 \\
\hline & Pearson Correlation &, $512^{* *}$ \\
\hline \multirow[t]{3}{*}{ MOTIVASI_6 } & Sig. (1-tailed) &, 000 \\
\hline & $\mathrm{N}$ & 35 \\
\hline & Pearson Correlation &, $611^{* *}$ \\
\hline \multirow[t]{3}{*}{ MOTIVASI_7 } & Sig. (1-tailed) &, 000 \\
\hline & $\mathrm{N}$ & 35 \\
\hline & $\begin{array}{l}\text { Pearson } \\
\text { Correlation }\end{array}$ &, $634^{* *}$ \\
\hline \multirow[t]{3}{*}{ MOTIVASI_8 } & Sig. (1-tailed) & ,000 \\
\hline & $\mathrm{N}$ & 35 \\
\hline & Pearson Correlation &, $641^{* *}$ \\
\hline \multirow[t]{3}{*}{ MOTIVASI_9 } & Sig. (1-tailed) & ,000 \\
\hline & $\mathrm{N}$ & 35 \\
\hline & Pearson Correlation &, $410^{* *}$ \\
\hline \multirow[t]{2}{*}{ MOTIVASI_10 } & Sig. (1-tailed) &, 000 \\
\hline & $\mathrm{N}$ & 35 \\
\hline
\end{tabular}


Arif Proyogo, Pengaruh Motivasi Dan Budaya Organisasi ...

\begin{tabular}{clc}
\hline & & Tot_Ekuitas_Merk \\
\hline \multirow{2}{*}{ MOTIVASI_11 } & Pearson Correlation &, $519^{* *}$ \\
& Sig. (1-tailed) &, 000 \\
& $\mathrm{~N}$ & 35 \\
MOTIVASI_12 & Pearson Correlation &, $693^{* *}$ \\
& Sig. (1-tailed) &, 000 \\
MOTIVASI_13 & $\mathrm{N}$ & 35 \\
& Pearson Correlation &, $526^{* *}$ \\
MOTIVASI_14 & Sig. (1-tailed) &, 000 \\
& $\mathrm{~N}$ & 35 \\
MOTIVASI_15 & Pearson Correlation &, $659^{* *}$ \\
& Sig. (1-tailed) &, 000 \\
MOTIVASI_16 & $\mathrm{N}$ & 35 \\
& Pearson Correlation &, $609^{* *}$ \\
& Sig. (1-tailed) &, 000 \\
MOTIVASI_17 & $\mathrm{N}$ & 35 \\
& Pearson Correlation &, $657^{* *}$ \\
& Sig. (1-tailed) &, 000 \\
& $\mathrm{~N}$ & 35 \\
& Pearson Correlation &, $735^{* *}$ \\
& Sig. (1-tailed) &, 000 \\
\hline
\end{tabular}

**. Correlation is significant at the 0.01 level (1-tailed).

*. Correlation is significant at the 0.05 level (1-tailed).

Sumber : Data Primer yang Diolah, 2014

Dari data di atas terlihat dengan jelas bahwa Motivasi dinyatakan valid. nilai $r$ hitung $>$ dari $r$ kritis $(0,3)$, sehingga data

Tabel Uji Validitas Variabel Budaya Organisasi Variabel Buadaya Organisasi Correlations

\begin{tabular}{|c|c|c|}
\hline & & $\begin{array}{c}\text { Tot_Kualitas_Pelayana } \\
\mathrm{n}\end{array}$ \\
\hline \multirow[t]{2}{*}{ Tot_Kualitas_Pelayanan } & $\begin{array}{l}\text { Pearson Correlation } \\
\text { Sig. (1-tailed) }\end{array}$ & 1 \\
\hline & $\mathrm{N}$ & 35 \\
\hline \multirow[t]{3}{*}{ BUD_ORG_1 } & Pearson Correlation &, $658^{* * *}$ \\
\hline & Sig. (1-tailed) &, 000 \\
\hline & $\mathrm{N}$ & 35 \\
\hline \multirow[t]{3}{*}{ BUD_ORG_2 } & Pearson Correlation &, $705^{* *}$ \\
\hline & Sig. (1-tailed) &, 000 \\
\hline & $\mathrm{N}$ & 35 \\
\hline \multirow[t]{3}{*}{ BUD_ORG_3 } & Pearson Correlation &, $613^{* *}$ \\
\hline & Sig. (1-tailed) &, 000 \\
\hline & $\mathrm{N}$ & 35 \\
\hline \multirow[t]{3}{*}{ BUD_ORG_4 } & Pearson Correlation &, $553^{* *}$ \\
\hline & Sig. (1-tailed) &, 000 \\
\hline & $\mathrm{N}$ & 35 \\
\hline \multirow[t]{3}{*}{ BUD_ORG_5 } & Pearson Correlation &, $689^{* *}$ \\
\hline & Sig. (1-tailed) &, 000 \\
\hline & $\mathrm{N}$ & 35 \\
\hline \multirow[t]{3}{*}{ BUD_ORG_6 } & Pearson Correlation &, $539^{* *}$ \\
\hline & Sig. (1-tailed) & ,000 \\
\hline & $\mathrm{N}$ & 35 \\
\hline \multirow[t]{3}{*}{ BUD_ORG_7 } & Pearson Correlation &, $581^{* *}$ \\
\hline & Sig. (1-tailed) &, 000 \\
\hline & $\mathrm{N}$ & 35 \\
\hline \multirow[t]{3}{*}{ BUD_ORG_8 } & Pearson Correlation &, $605^{* *}$ \\
\hline & Sig. (1-tailed) & ,000 \\
\hline & $\mathrm{N}$ & 35 \\
\hline \multirow[t]{3}{*}{ BUD_ORG_9 } & Pearson Correlation &, $676^{* *}$ \\
\hline & Sig. (1-tailed) &, 000 \\
\hline & $\mathrm{N}$ & 35 \\
\hline \multirow[t]{3}{*}{ BUD_ORG_10 } & Pearson Correlation &, $583^{* *}$ \\
\hline & Sig. (1-tailed) &, 000 \\
\hline & $\mathrm{N}$ & 35 \\
\hline
\end{tabular}


Majalah Ilmiah Ilmu Administrasi

ISSN 1411-0830

\begin{tabular}{llr}
\hline & & Tot_Kualitas_Pelayana \\
& & $\mathrm{n}$ \\
\hline BUD_ORG_11 & Pearson Correlation &, $654^{* *}$ \\
& Sig. (1-tailed) &, 000 \\
BUD_ORG_12 & Pearson Correlation & 35 \\
& Sig. (1-tailed) &, $570^{* *}$ \\
& N &, 000 \\
BUD_ORG_13 & Pearson Correlation & 35 \\
& Sig. (1-tailed) &, $588^{* *}$ \\
& N &, 000 \\
BUD_ORG_14 & Pearson Correlation & 35 \\
& Sig. (1-tailed) &, $669^{* *}$ \\
& N &, 000 \\
BUD_ORG_15 & Pearson Correlation & 35 \\
& Sig. (1-tailed) &, $692^{* *}$ \\
& N &, 000 \\
BUD_ORG_16 & Pearson Correlation & 35 \\
& Sig. (1-tailed) &, $687^{* *}$ \\
& N &, 000 \\
& the 0.01 level (1-tailed). & 35 \\
\hline
\end{tabular}

**. Correlation is significant at the 0.01 level (1-tailed).

*. Correlation is significant at the 0.05 level (1-tailed).

Sumber : Data Primer yang Diolah, 2014

Dari data di atas terlihat dengan jelas bahwa

data Budaya Organisasi dinyatakan valid nilai $r$ hitung $>$ dari $r$ kritis $(0,3)$, sehingga

Tabel Uji Validitas Variabel Produktifitas Kerja Variabel Produktifitas Kerja

\begin{tabular}{|c|c|c|c|}
\hline \multicolumn{4}{|c|}{ Correlations } \\
\hline \multirow[t]{22}{*}{$\begin{array}{l}\text { Spearman's } \\
\text { rho }\end{array}$} & Prod_Kerja1 & $\begin{array}{l}\text { Correlation Coefficient } \\
\text { Sig. (1-tailed) }\end{array}$ & $\begin{array}{r}\text { Tot_Prod_Kerja } \\
.779^{* *} \\
.000\end{array}$ \\
\hline & Prod Kerja2 & $\begin{array}{l}\mathrm{N} \\
\text { Correlation Coefficient }\end{array}$ & $\begin{array}{r}35 \\
.854^{* *}\end{array}$ \\
\hline & & Sig. (1-tailed) & .000 \\
\hline & & $\mathrm{N}$ & 35 \\
\hline & Prod_Kerja3 & Correlation Coefficient & $.845^{* *}$ \\
\hline & & Sig. (1-tailed) & .000 \\
\hline & & $\mathrm{N}$ & 35 \\
\hline & Prod_Kerja4 & Correlation Coefficient & $.867^{* *}$ \\
\hline & & Sig. (1-tailed) & .000 \\
\hline & & $\mathrm{N}$ & 35 \\
\hline & Prod_Kerja5 & Correlation Coefficient & $.862^{* *}$ \\
\hline & & Sig. (1-tailed) & .000 \\
\hline & & $\mathrm{N}$ & 35 \\
\hline & Prod_Kerja6 & Correlation Coefficient & $.813^{* *}$ \\
\hline & & Sig. (1-tailed) & .000 \\
\hline & & $\mathrm{N}$ & 35 \\
\hline & Prod_Kerja7 & Correlation Coefficient & $.811^{* *}$ \\
\hline & & Sig. (1-tailed) & .000 \\
\hline & & $\mathrm{N}$ & 35 \\
\hline & Prod_Kerja8 & Correlation Coefficient & $.710^{* *}$ \\
\hline & & Sig. (1-tailed) & .000 \\
\hline & & $\mathrm{N}$ & 35 \\
\hline
\end{tabular}


Arif Proyogo, Pengaruh Motivasi Dan Budaya Organisasi ...

\begin{tabular}{llr}
\hline \multicolumn{3}{c}{ Correlations } \\
\hline Prod_Kerja9 & Correlation Coefficient & $.802^{* * *}$ \\
& Sig. (1-tailed) & .000 \\
& N & 35 \\
Prod_Kerja10 & Correlation Coefficient & $.792^{* *}$ \\
& Sig. (1-tailed) & .000 \\
& N & 35 \\
Prod_Kerja11 & Correlation Coefficient & $.856^{* *}$ \\
& Sig. (1-tailed) & .000 \\
& N & 35 \\
& Correlation Coefficient & $.872^{* *}$ \\
& Sig. (1-tailed) & .000 \\
& N & 35 \\
& Correlation Coefficient & 1.000 \\
& Sig. (1-tailed) &. \\
& N & 35 \\
\hline
\end{tabular}

**. Correlation is significant at the 0.01 level (1-tailed).

Sumber : Data Primer yang Diolah, 2014

Dari hasil pengolahan data di atas terlihat dengan jelas bahwa dapat dijelaskan nilai $r$ hitung lebih besar dari $\mathrm{r}$ tabel $(0,3)$ dengan demikian dapat disimpulkan bahwa semua data variable Produktifitas Kerja adalah valid.

Uji Reliabilitas

Uji reliabilitas digunakan untuk mengukur konsistensi dari suatu variabel. Butir pertanyaan dalam variabel dikatakan reliabel atau terpercaya apabila jawaban responden adalah konsisten atau stabil dari waktu ke waktu. Suatu konstruk atau variabel dikatakan reliabel jika emiberikan nilai Cronbach Alpha $\geq 0,60$. Adapun hasil uji reliabilitas variabel Motivasi, Budaya Organisasi dan Produktifitas Kerja dapat dilihat pada tabel berikut ini.

Hasil Uji Reliabilitas

Tabel Reliability Statistics of Motivasi

Reliability Statistics

Of Motivasi

Reliability Statistics

Cronbach's Alpha N of Motivasis

,901 17

*. Correlation is significant at t84he 0.01 level (1-tailed).

Sumber : Data primer yang diolah, 2014

Tabel Reliability Statistics Budaya

Organisasi 


\author{
Reliability Statistics Of Budaya Organisasi \\ Reliability Statistics \\ \begin{tabular}{ll}
\hline Cronbach's Alpha & N of Bud_Org \\
\hline 928 & 16
\end{tabular} \\ *. Correlation is significant at the 0.01 level (1-tailed). \\ Sumber : Data primer yang diolah, 2014 \\ Tabel Reliability Statistics of Produktifitas Kerja \\ Reliability Statistics of Produktifitas Kerja \\ Reliability Statistics \\ Cronbach's Alpha N of Prod-Kerja

$\begin{array}{ll}\text {,755 } & 12\end{array}$ \\ *. Correlation is significant at the 0.01 level (1-tailed). \\ Sumber : Data primer yang diolah, 2014
}

Berdasarkan tabel diatas dapat diketahui bahwa masing-masing variabel antara variabel Motivasi, Budaya Organisasi dan Produktifitas Kerja, ternyata diperoleh nilai Cronbach Alpha $\geq 0,60$. Dengan demikian, maka hasil uji

reabilitas terhadap keseluruhan variabel adalah reliabel.

\section{Analisis Kualitatif}

Variabel Motivasi (X1)

Tabel 11 Tanggapan Responden Terhadap Variabel Motivasi

\begin{tabular}{|c|c|c|c|c|c|c|c|}
\hline No & Indikator & SS & S & $\mathrm{CS}$ & $\mathrm{TS}$ & STS & Skor \\
\hline 1 & Kondisi tempat kerja sudah baik dan mendukun & 14 & 13 & 6 & 4 & 1 & 4.21 \\
\hline 2 & Gaji yang diberikan perusahaan sudah sesuai & 5 & 18 & 10 & 1 & 1 & 3.73 \\
\hline 3 & Penyediaan ruang kerja sudah memadai dan mendukung & 15 & 14 & 5 & 0 & 1 & 4.29 \\
\hline 4 & Penyediaan Sarana kerja sudah memadai dan mendukung & 4 & 18 & 12 & 1 & 0 & 3.72 \\
\hline 5 & Fasilitas kerja sudah memadai dan mendukung & 12 & 18 & 5 & 0 & 0 & 4.21 \\
\hline 6 & Jaminan keamanan lingkungan kerja sudah baik & 5 & 18 & 11 & 1 & 0 & 3.79 \\
\hline 7 & Dukungan pengamanan lam pelaksanaan kerja sudah baik & 8 & 19 & 8 & 0 & 0 & 3.99 \\
\hline 8 & Perlindungan terhadap resiko pekerjaan sudah baik & 9 & 16 & 9 & 0 & 1 & 3.86 \\
\hline 9 & Penghargaan kerja sudah baik & 10 & 20 & 4 & 0 & 0 & 4.13 \\
\hline 10 & Promosi Jabatan sudah baik & 16 & 14 & 4 & 1 & 0 & 4.27 \\
\hline 11 & Penghargaan masyarakat terbangun baik & 9 & 16 & 7 & 3 & 0 & 3.90 \\
\hline 12 & Hubungan antar sesama karyawan baik & 7 & 17 & 10 & 1 & 0 & 3.84 \\
\hline 13 & Dukungan sesama karyawan baik & 6 & 13 & 11 & 3 & 2 & 3.50 \\
\hline 14 & Hubungan dengan lembaga baik & 4 & 12 & 17 & 1 & 1 & 3.44 \\
\hline 15 & Aktualisasi identitas diri anda terbangun & 2 & 11 & 18 & 4 & 1 & 3.24 \\
\hline 16 & Aktualisasi profesionalitas masyarakat terbangun & 2 & 13 & 18 & 1 & 0 & 3.48 \\
\hline \multirow[t]{3}{*}{17} & Aktualisasi akuntabilitas masyarakat terbangun & 4 & 17 & 13 & 1 & 0 & 3.73 \\
\hline & Total Skor & & & & & & 65,32 \\
\hline & Rata-rata Skor & & & & & & 3,84 \\
\hline
\end{tabular}

Sumber : Data primer yang diolah 2014

Berdasarkan tabel 4.1 diatas diketahui bahwa skor jawaban responden untuk variable Motivasi adalah 3,84 berada pada kategori baik $(3,00-$ 4,00). Hal ini mengindikasikan bahwa responden merespon baik Motivasi.
Dengan demikian dapat dikatakan bahwa semakin baik Motivasi, maka akan semakin baik Produktifitas Kerja.

a. Tabel Variabel Budaya Organisasi (X2)

\begin{tabular}{clrrrrrr}
\hline No & Indikator & SS & S & CS & TS & STS & Skor \\
\hline 1 & Iklim kerja memberikan kesempatan berinovasi kepada anda & 6 & 14 & 13 & 2 & 1 & 3.68 \\
\hline
\end{tabular}


Arif Proyogo, Pengaruh Motivasi Dan Budaya Organisasi ...

\begin{tabular}{|c|c|c|c|c|c|c|c|}
\hline 2 & Anda Siap Menghadapi resiko dalam bekerja & 5 & 18 & 12 & 1 & 1 & 3.89 \\
\hline 3 & Dalam bekerja anda mampu berorientasi kepada orang & 6 & 11 & 15 & 3 & 4 & 3.61 \\
\hline 4 & $\begin{array}{l}\text { Dalam bekerja anda mampu berorientasi kepada hasil kerja dan } \\
\text { tim }\end{array}$ & 0 & 4 & 19 & 10 & 10 & 2.99 \\
\hline 5 & Anda mampu bekerja secara agresip & 3 & 14 & 16 & - & 1 & 3.53 \\
\hline 6 & Dalam bekerja anda mampu menetapkan nilai-nilai positif & 5 & 11 & 16 & 3 & 1 & 3.56 \\
\hline 7 & $\begin{array}{l}\text { Budaya organisasi mampu menumbuhkan pembinaan terhadap } \\
\text { anggota }\end{array}$ & 2 & 9 & 18 & 4 & 6 & 3.33 \\
\hline 8 & Budaya Organisasi mampu menumbuhkan contoh teladan & 2 & 16 & 15 & 4 & 0 & 3.65 \\
\hline 9 & Budaya organisasi mampu membangun acara rutini & 3 & 19 & 13 & 0 & 0 & 3.71 \\
\hline 10 & $\begin{array}{l}\text { Budaya organisasi mampu menumbuhkan penilaian dan } \\
\text { penghargaan }\end{array}$ & 4 & 16 & 15 & 1 & 0 & 3.64 \\
\hline 11 & $\begin{array}{l}\text { Budaya organisasi mampu menumbuhkan sikap dalam } \\
\text { melayani }\end{array}$ & 4 & 18 & 12 & 0 & 0 & 3.75 \\
\hline 12 & $\begin{array}{l}\text { Budaya organisasi mampu menumbuhkan sikap dalam } \\
\text { melaksanakan pekerjaan }\end{array}$ & 4 & 18 & 12 & 0 & 0 & 3.76 \\
\hline 13 & Budaya organisasi mamapu menumbuhkan sikap inisiatif kerja & 3 & 13 & 15 & 1 & 0 & 3.22 \\
\hline 14 & $\begin{array}{l}\text { Budaya Organisasi mampu menumbuhkan ketrampilan } \\
\text { pencapaian tugas }\end{array}$ & 4 & 18 & 17 & 0 & 0 & 4.02 \\
\hline 15 & $\begin{array}{l}\text { Budaya Organisasi mampu menumbuhkan ketrampilan } \\
\text { melaksanakan program }\end{array}$ & 6 & 17 & 18 & 0 & 1 & 4.43 \\
\hline 16 & $\begin{array}{l}\text { Budaya organisasi memapu menumbuhkan ketrampilan } \\
\text { mengevaluasi pencapaian program }\end{array}$ & 3 & 16 & 15 & 0 & 0 & 3.62 \\
\hline & Total Skor & & & & & & 58,38 \\
\hline & Rata-rata Skor & & & & & & 3,65 \\
\hline
\end{tabular}

Sumber : Data primer yang diolah 014

Berdasarkan tabel 4.2 diatas diketahui bahwa skor jawaban responden untuk variabel Budaya Organisasi adalah 3.65 berada pada kategori cukup baiki $(3.00-4.00)$. Hal ini mengindikasikan bahwa responden (mahasiswa) menilai bahwa Budaya Organisasi yang diberikan lembaga telah cukup sesuai dengan

\section{TINJAUAN PUSTAKA}

Strategi dan Daya Saing Industri Penerbangan Bertarif Rendah

Perusahaan (maskapai) penerbangan bertarif rendah di dunia telah menerapkan model bisnis secara umum (wikipedia, maskapai penerbangan bertarif rendah), yaitu meliputi : pertama, sebuah kelas penumpang tunggal. Kedua, sebuah tipe pesawat terbang bersayap tetap (umumnya Airbus A320 atau Boeing 737) tunggal, mengurangi biaya pelatihan dan pengoperasian. Ketiga, mengurangi peralatan kecil di pesawat, agar dapat mengurangi biaya perawatan. Keempat, sebuah cara menerapkan harga tetap, seperti memberi harga tiket ulang alik senilai setengah harga tiket jika hanya membeli satu arah tujuan (one way). Kelima, terbang murah dengan terbang awal di pagi atau sore hari untuk menghindari penundaan lalu lintas udara karena traffic dan pajak untuk pendaratannya (landing) lebih rendah. Keenam, rentang waktu terbang pulang pergi yang cepat (membolehkan penggunaan pesawat secara maksimum). Ketujuh, rute yang dipermudah, menekankan perpindahan titik-ke-titik (transit) di bandara utama dengan membolehkan penggunaan pesawat dalam rute yang sama untuk mengurangi penumpang dan barang bawaan yang tertunda atau tertinggal. Kedelapan, mengutamakan penjualan tiket secara langsung, khususnya melalui internet (menghindari pajak dan komisi terhadap agen perjalanan dan sistem reservasi komputer). Kesembilan, membolehkan penggunaan dan pengambilan melalui tiket elektronik atau perjalanan tanpa tiket. Kesepuluh, karyawan harus bisa melaksanakan berbagai pekerjaan, seperti pramugari yang juga membersihkan pesawat atau bekerja sebagai petugas gerbang untuk membatasi gaji perorangan. Kesebelas, dihapusnya pemberian makanan gratis dan layanan cuma-cuma didalam penerbangan, dan digantikan dengan pilihan makanan dan minuman yang dibayar untuk menghasilkan sumber keuntungan tambahan bagi maskapai. Kedua belas, tidak menangani sebuah layanan khusus bagi penumpang, contohnya dengan menaruh batas usia yang tinggi pada 
Unaccompanied Minors (UM) daripada maskapai layanan penuh. Ketiga belas, menerapkan program lindung nilai bahan bakar yang agresif. Keempat belas, biaya tambahan (seperti pajak bandara, dan pajak lainnya dijadikan sebagai biaya yang dipisah dari harga tiket yang diiklankan) untuk membuat harga tiket terlihat rendah

Tidak setiap maskapai bertarif rendah melaksanakan kelima belas persyaratan di atas, contohnya beberapa maskapai mencoba membedakan dirinya dengan menerapkan kursi yang ditentukan, sementara yang lainnya beroperasi lebih dari satu tipe pesawat, atau memiliki biaya operasi yang tinggi tetapi harga rendah). Walaupun begitu ini merupakan karakteristik umum, beberapa diantaranya berlaku kepada maskapai bertarif rendah yang yang ada.

Karakteristik dan Evolusi Jaringan Operasi Ryanair Ltd

Malighetti et. al (2009), Jaringan Ryanair Ltd., ditandai oleh ekspansi yang mantap dan sangat dinamis. Perbandingan data yang dikumpulkan pada tanggal 1 Juli 2005 sampai dengan tanggal 30 Juni 2006, memberikan gambaran jelas tentang fenomena tersebut. Sebagai gambaran pada bulan Juli 2005, Ryanair Ltd., dilayani di 95 bandara dan meningkat menjadi 111 bandara setahun kemudian pada periode yang sama dengan rute penerbangan yang diperluas $34,4 \%$ mencapai 594 rute, hal ini diperlihatkan pada tabel 1, dibawah ini

b. Variabel Produktifitas Kerja (Y) Tabel Tanggapan Responden Terhadap Variabel Produktifitas Kerja

\begin{tabular}{|c|c|c|c|c|c|c|c|}
\hline No & Indikator & SS & $\mathrm{S}$ & CS & TS & STS & Skor \\
\hline 1 & $\begin{array}{l}\text { Hubungan kerja anda dengan pimpinan terbangun } \\
\text { dengan baik }\end{array}$ & 8 & 15 & 10 & 2 & - & 3.83 \\
\hline 2 & Hubungan kerja anda dengan antar bagian berjalan baik & 15 & 12 & 8 & 1 & - & 4.16 \\
\hline 3 & Hubungan kerja anda dengan rekan sekerja berjalan baik & 24 & 8 & 2 & 1 & 1 & 4.53 \\
\hline 4 & Koordinasi pekerjaan anda berjalan baik & 18 & 9 & 8 & 2 & - & 4.20 \\
\hline 5 & Komunikasi anda dengan antar bagian berjalan baik & 18 & 7 & 9 & - & - & 4.16 \\
\hline 6 & Tanggungjawab pekerjaan anda berjalan baik. & 15 & 15 & 5 & 1 & - & 4.23 \\
\hline 7 & Jumlah tenaga kerja sudah memadai & 6 & 14 & 13 & 2 & 1 & 3.63 \\
\hline 8 & Pemanfaatan tenaga kerja sudah berjalan baik & 5 & 13 & 14 & 3 & 1 & 3.50 \\
\hline 9 & Pemanfaatan waktu tenaga kerja berjalan optimal & 4 & 15 & 14 & 2 & 1 & 3.53 \\
\hline 10 & $\begin{array}{l}\text { Kemampuan nda dalam melihat potensi daerah sudah } \\
\text { berjalan baik }\end{array}$ & 5 & 13 & 14 & 4 & 1 & 3.51 \\
\hline 11 & $\begin{array}{l}\text { Kemampuan anda dalam melihat potensi diri sudah } \\
\text { berjalan baik }\end{array}$ & 4 & 14 & 13 & 5 & 1 & 3.40 \\
\hline 12 & $\begin{array}{l}\text { Kemampuan anda dalam melihat potensi organisasi } \\
\text { sudah berjalan baik }\end{array}$ & 4 & 10 & 13 & 9 & 1 & 3.19 \\
\hline & $\begin{array}{l}\text { Total Skor } \\
\text { Rata-rata Skor }\end{array}$ & & & & & & $\begin{array}{r}45,86 \\
3,82\end{array}$ \\
\hline
\end{tabular}

Sumber : Data primer yang diolah, 2014

Berdasarkan tabel 4.3 diatas diketahui bahwa skor jawaban responden untuk variabel Produktifitas Kerja adalah 3.82 berada pada kategori baik (3.00-4.00). Hal ini mengindikasikan bahwa produktifitas karyawan sudah cukup baik

\section{Analisis Kuantitatif}

\section{Uji Asumsi Klasik}

Uji Multikolinearitas

Uji multikolinearitas bertujuan untuk menguji apakah pada model regresi terdapat adanya korelasi antar variabel independen. Jika terjadi korelasi, maka dinamakan terdapat Multikolinearitas. Model regresi yang baik seharusnya tidak terjadi korelasi di antara variabel independen.

Deteksi tidak adanya Multikolinearitas yakni dengan melihat besaran VIF (Variance 
Arif Proyogo, Pengaruh Motivasi Dan Budaya Organisasi ...

Inflation Factor) dan Tolerance (Ghozali, 2006):

- Mempunyai nilai VIF $<10$

- Mempunyai angka TOLERANCE > 10\%

Mengacu pada kedua pendapat di atas maka berdasarkan hasil penelitian yang telah dilakukan dapat diperoleh nilai :

Tabel 14. Tabel Hasil Uji Multikolinearitas

Pengecekan Multikolinearitas

\begin{tabular}{lcr}
\hline Model & \multicolumn{2}{c}{ Collinearity Statistics } \\
Tolerance & VIF \\
\hline (Constant) &, 410 & \\
Motivasi_Karyawan &, 410 & 2,440 \\
Budaya_Organisasi & 2,440 \\
\hline a. Dependent Variable: Citra_Politeknik & &
\end{tabular}

Sumber : data Primer yang Diolah, 2014

Berdasarkan hasil tersebut maka dalam model regresi tidak terjadi multikolinearitas atau korelasi yang ditunjukkan antara variabelvariabel bebas, yaitu Motivasi, Budaya Organisasi dan Produktifitas Kerja, karena nilai VIF lebih kecil dari 10 dan nilai tolerance lebih besar dari 0,1 .

\section{Uji Heteroskedastisitas}

Heteroskedastisitas terjadi apabila tidak ada kesamaan deviasi standar nilai variabel dependen pada setiap variabel independen. Deteksi dengan melihat ada tidaknya pola tertentu pada grafik berikut ini:

\section{Gambar 9. Pengujian Heteroskedastisitas}

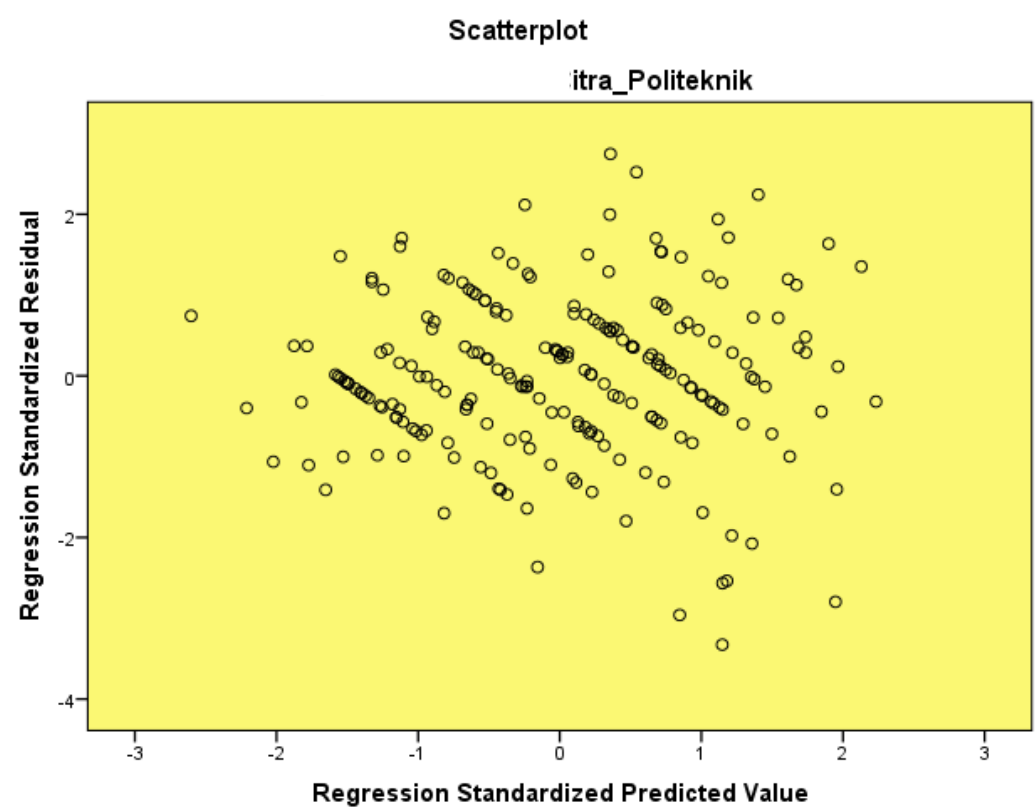

Sisaan Homogen (Asumsi terpenuhi)

Gambar 9. Gambar Hasil Uji Heterokedastisitas

Sumber : Data primer yang diolah, 2014

Dari grafik tersebut, dapat terlihat titiktitik yang menyebar secara acak, tidak menunjukkan bentuk suatu pola tertentu yang jelas, serta tersebar baik di atas maupun di bawah angka 0 (nol) pada sumbu Y, maka tidak terjadi heteroskedastisitas.

\section{Uji Normalitas}

Uji normalitas bertujuan untuk menguji apakah dalam model regresi, variabel terikat dan variabel bebas atau keduanya mempunyai distribusi normal atau tidak. Model regresi yang baik adalah memiliki distribusi data normal atau mendekati normal. Deteksi dengan melihat 
penyebaran data (titik) pada sumbu diagonal dari grafik. Dasar pengambilan keputusan: a). Jika data menyebar disekitar garis diagonal dan mengikuti arah garis diagonal, maka model regresi memenuhi asumsi normalitas; b). Jika data menyebar jauh dari garis diagonal dan tidak mengikuti arah garis diagonal, maka model regresi tidak memenuhi asumsi normalitas. regresi tidak
Probability Plot

\section{Normal Probability Plot}

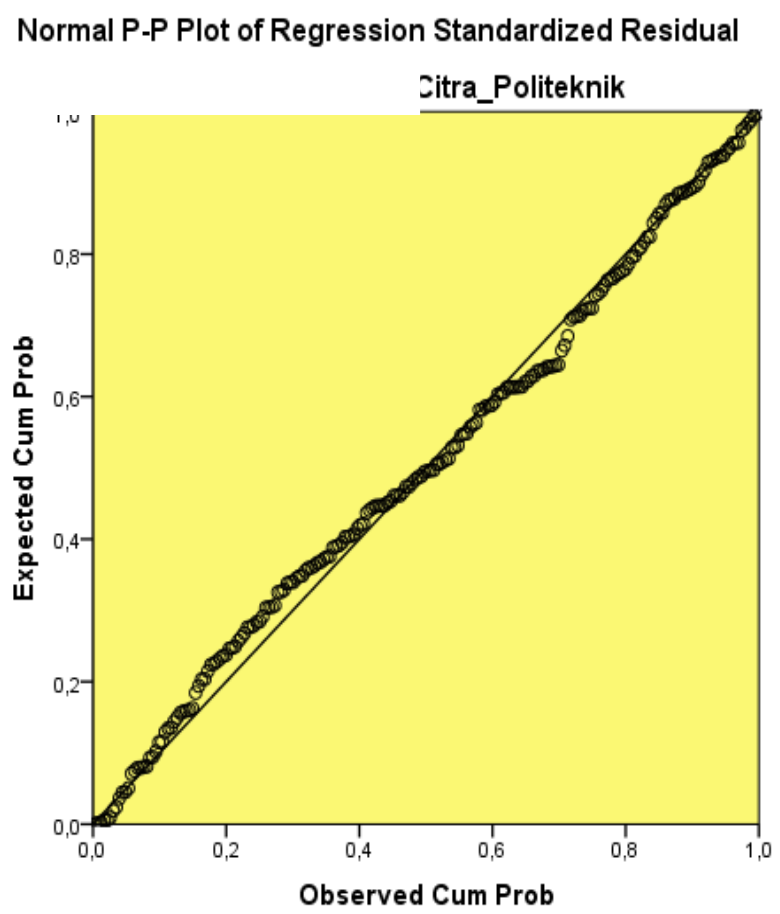

Normalitas (Sisaan menyebar normal: Asumsi Terpenuhi)

Gambar 10. Hasil Pengujian Normalitas

Sumber : Data primer yang diolah, 2014

Berdasarkan hasil analisis data dengan menggunakan SPSS, maka dapat diketahui bahwa data menyebar disekitar garis diagonal dan mengikuti arah garis diagonal, maka model regresi memem asumsi normalitas.

\section{Analisis Regresi Linier Berganda}

Berdasarkan perhitungan regresi berganda antara Motivasi (X1), Budaya Organisasi (X2) terhadap Produktifitas Kerja (Y) dengan dibantu program SPSS dalam perhitungannya dapat diperoleh hasil sebagai berikut

Tabel 15. Tabel Ringkasan Hasil Estimasi Regresi

\begin{tabular}{lrrrrr}
\hline & \multicolumn{5}{c}{$\begin{array}{c}\text { Standardized } \\
\text { Coefficients }\end{array}$} \\
Model & B & Std. Error & Beta & T & Sig. \\
\hline (Constant) &, 242 &, 200 & & 1,211 &, 227 \\
Motivasi_Kerja &, 286 &, 086 &, 223 & 3,312 &, 001 \\
Budaya_Organisasi &, 699 &, 079 &, 591 & 8,795 &, 000 \\
\hline
\end{tabular}

Dependent Variable: Motivasi_Kerja

Sumber : Data yang diolah 2014

Berdasarkan tabel di atas, maka persamaan regresi yang terbentuk pada uji regresi ini adalah : $\mathrm{Y}=0.242+0.286 \mathrm{X} 1+$ $0.699 \times 2$.
Berdasarkan persamaan dapat diketahui bahwa: a. Nilai koefisien regresi variabel Motivasi sebesar 0,286 bernilai positif mempunyai arti bahwa jika semakin baik Motivasi, maka Produktifitas Kerja akan 
Arif Proyogo, Pengaruh Motivasi Dan Budaya Organisasi ...

semakin meningkat; dan b. Nilai koefisien regresi variabel media Budaya Organisasi sebesar 0.699 bernilai positif mempunyai arti bahwa jika Budaya Organisasi semakin baik, maka Produktifitas Kerja akan meningkat.

\section{Pengujian Hipotesis}

Uji $t$

Uji t ini digunakan untuk mengetahui ada atau tidaknya pengaruh antara Motivasi (X1) dan Budaya Organisasi (X2) terhadap Produktifitas Kerja (Y) secara parsial.

Perumusan hipotesis

$\mathrm{H} 0: \beta<0$ : tidak ada pengaruh yang positif dan signifikan antara Motivasi (X1) dan Budaya Organisasi (X2) terhadap Produktifitas Kerja (Y)

Ha $: \beta>0$ : ada pengaruh yang positif dan signifikan antara Motivasi (X1), Budaya Organisasi (X2) terhadap Produktifitas Kerja (Y)

Melalui perhitungan dengan menggunakan program SPSS dapat diketahui sebagai berikut

Hipotesis 1 : Motivasi Mempunyai Pengaruh Yang Positif Terhadap Produktifitas Kerja

Dari hasil perhitungan diperoleh nilai $t$ hitung untuk variabel Motivasi adalah sebesar 3.312 dan dengan menggunakan level significance (taraf signifikasi) sebesar 5\% diperoleh $\mathrm{t}$ tabel $(\mathrm{t} \alpha / 2, \mathrm{n}-\mathrm{k}-1=\mathrm{t} \alpha / 2,218-2-1=$ 2,257) sebesar 2,257 yang berarti bahwa nilai t hitung lebih dari t tabel yaitu $3.312>2,257$.
Nilai signifikasi t kurang dari $5 \% \quad(0,001)$, menandakan bahwa Motivasi (X1) mempunyai pengaruh positif yang signifikan terhadap Produktifitas Kerja (Y) pada taraf nyata $10 \%$. Dengan demikian dapat disimpulkan bahwa Ho ditolak dan H1 diterima, sehingga hipotesis yang menyatakan Motivasi mempunyai pengaruh terhadap Produktifitas Kerja dapat diterima.

Hipotesis 2 : Budaya Organisasi Mempunyai Pengaruh Yang Positif Terhadap Produktifitas Kerja

Dari hasil perhitungan diperoleh nilai $\mathrm{t}$ hitung untuk variabel harga adalah sebesar 8,795 dan dengan menggunakan level significance (taraf signifikasi) sebesar 5\% diperoleh $\mathrm{t}$ tabel sebesar 2,257 yang berarti bahwa nilai t hitung lebih besar dari t tabel yaitu $8,795>2,257$. Nilai signifikasi t kurang dari $105 \%(0,000)$, menandakan bahwa Budaya Organisasi (X2) mempunyai pengaruh yang positif dan signifikan terhadap Produktifitas Kerja (Y). Dengan demikian dapat disimpulkan bahwa Ho ditolak dan H1 diterima, sehingga hipotesis yang menyatakan Budaya Organisasi mempunyai pengaruh yang positif terhadap Produktifitas Kerja dapat diterima.

\section{Uji F}

Dalam melakukan uji $\mathrm{F}$, parameter yang digunakan adalah dengan membanndingkan Fhitung > F-tabel. Pengujian terhadap pengaruh variabel bebas terhadap variabel terikat secara simultan dilakukan dengan uji $\mathrm{F}$ dengan hasil yang dapat dilihat pada tabel 4.7 berikut ini.

\begin{tabular}{|c|c|c|c|c|c|}
\hline \multicolumn{6}{|c|}{$\begin{array}{c}\text { Tabel Nilai } \boldsymbol{U j j i}_{\mathbf{j}} \boldsymbol{F} \\
\text { ANOVA }^{\mathbf{b}}\end{array}$} \\
\hline Model & $\begin{array}{l}\text { Sum of } \\
\text { Squares }\end{array}$ & Df & $\begin{array}{l}\text { Mean } \\
\text { Square }\end{array}$ & $\mathrm{F}$ & Sig. \\
\hline Regression & 62,345 & 2 & 31,173 & 162,322 &, $000^{\mathrm{b}}$ \\
\hline Residual & 41,289 & 215 & ,192 & & \\
\hline Total & 103,635 & 217 & & & \\
\hline
\end{tabular}

Sumber : Data yang diolah 2014

Berdasarkan tabel 4.7. menunjukkan hasil perhitungan uji $\mathrm{F}$ diperoleh nilai F-hitung sebesar 162,322 dengan tingkat signifikansi sebesar $0,000(<0,05)$. 
Majalah Ilmiah Ilmu Administrasi

ISSN 1411-0830

Sementara nilai F-tabel sebesar 3,038 (dari perhitungan $\mathrm{dk} 1=2$, alpha $=0,05 \mathrm{dan} \mathrm{dk}=$ $218-2-1=215$ diperoleh $\mathrm{F}$ table 3,038). Ini berarti bahwa F-hitung (162,322)> Ftabel (3,038) dengan demikian Ho ditolak dan H1 diterima, artinya bahwa Motivasi dan Budaya Organisasi berpengaruh signifikan secara simultan atau bersama-sama terhadap Produktifitas Kerja.

\section{Korelasi Product Moment (Korelasi dan Determinasi)}

Menurut Sugiyono (2009; 228), Korelasi Product Moment merupakan suatu Teknik korelasi yang digunakan untuk mencari hubungan dan membuktikan hipotesis hubungan dua variable bila data kedua variable berbentul interval atau ratio, dan sumber data dari dua variable atau lebih tersebut adalah sama.

Berikut ini dikemukakan rumus yang paling sederhana yang dapat digunakan untuk menghitung koefesien korelasi adalah sebagai berikut :

$$
r_{x y}=\frac{n \sum x y-\left(\sum x\right)\left(\sum y\right)}{\sqrt{\left.\left(n \sum x^{2}-\left(\sum x\right)^{2}\right)\left(n \sum y^{2}\right)-\left(\sum y\right)^{2}\right)}}
$$

Dimana :

rxy $=$ Korelasi antara variable $\mathrm{x}$ dengan

$$
\mathrm{y}
$$

$\mathrm{x}=$ variable $\mathrm{x}$

$\mathrm{x}=$ variable $\mathrm{y}$

\section{Korelasi Hubungan antara Motivasi dengan Produktifitas Kerja}

Tabel Model Summary Koefisien Determinasi

Model Summary ${ }^{\text {b }}$

\begin{tabular}{ccccc}
\hline Model & $\mathrm{R}$ & $\mathrm{R}$ Square & Adjusted R Square & Std. Error of the Estimate \\
\hline 1 & $.815^{\mathrm{a}}$ & .664 & .665 & 8.62980 \\
\hline
\end{tabular}

a. Predictors: (Constant), Motivasi Kerja

b. Dependent Variable: Produktifitas Kerja

Sumber : Data Primer yang Diolah, 2014

Dari table di atas dapat diketahui bahwa besarnya nilai koefisien korelasi antara Motivasi dan Produktifitas Kerja ditunjukkan oleh nilai $r$ sebesar 0.815 yang berarti hubungan diantara

\section{Korelasi Hubungan antara Budaya Organisasi dengan Produktifitas Kerja} keduanya kuat.

Tabel Model Summary Koefisien Determinasi

\section{Model Summary ${ }^{\mathrm{b}}$}

\begin{tabular}{lcccc}
\hline Model & $\mathrm{R}$ & $\mathrm{R}$ Square & Adjusted R Square & Std. Error of the Estimate \\
\hline 1 & $.747^{\mathrm{a}}$ & .558 & .568 & .43362 \\
\hline a. Predictors: (Constant), Budaya Organisasi & & \\
b. Dependent Variable: Produktifitas Kerja & &
\end{tabular}

Sumber : Data Primer yang Diolah, 2014

Berdasarkan data table di atas dapat diketahui bahwa besarnya nilai koefisien korelasi antara Budaya Organisasi dan Produktifitas Kerja ditunjukkan oleh nilai $r$ sebesar 0.747 yang berarti hubungan diantara keduanya sangat kuat. diterangkan oleh variabel lain yang tidak diajukan dalam penelitian ini.

\section{Koefisien Determinasi antara Motivasi Kerja dan Budaya Kerja dengan Produktifitas Kerja}

Untuk mengetahui besarnya pengaruh Motivasi dan Budaya Organisasi terhadap Produktifitas Kerja dapat dilihat dari besarnya nilai adjusted $\mathrm{R}^{2}$ 
Tabel Model Summary Koefisien Determinasi

Model Summary ${ }^{b}$

\begin{tabular}{llrrr}
\hline Model & $\mathrm{R}$ & $\mathrm{R}$ Square & Adjusted R Square & Std. Error of the Estimate \\
\hline 1 &, $776^{\mathrm{a}}$ &, 602 &, 598 &, 43823 \\
\hline a. Predictors: (Constant), Motivasi, Budaya kerja & & \\
b. Dependent Variable: Produktifitas Kerja &
\end{tabular}

Sumber : Data Primer yang Diolah, 2014

Berdasarkan data table di atas dapat diketahui bahwa besarnya nilai koefisien korelasi antara Motivasi, Budaya Organisasi dan Produktifitas Kerja ditunjukkan oleh nilai $r$ sebesar 0.776 yang berarti hubungannya sangat

\section{Koefisien Determinasi}

Untuk mengetahui besarnya pengaruh Motivasi, Budaya Organisasi dapat dilihat dari besarnya nilai $\mathrm{R}^{2}$ kuat.

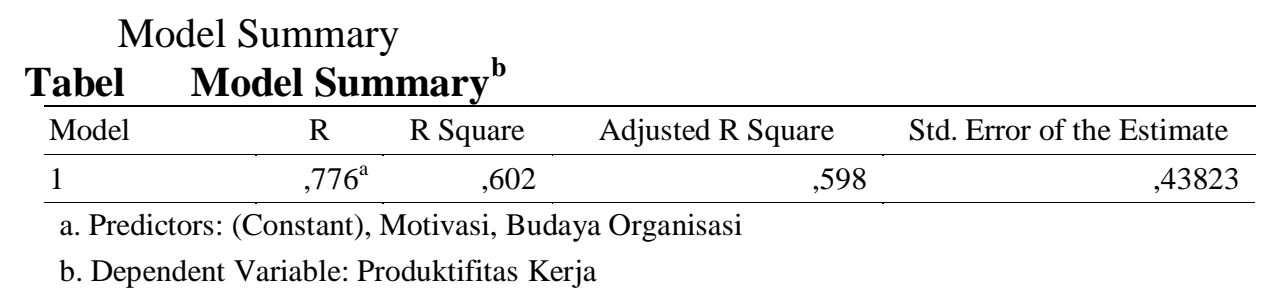

Berdasarkan tabel di atas, dapat diketahui bahwa besarnya nilai koefisien determinasi ditunjukkan oleh nilai $\mathrm{R}$ Square yaitu sebesar 0.602 yang artinya bahwa variasi dari variabel bebas yaitu Motivasi dan Budaya Organisasi dapat menerangkan variabel Produktifitas Kerja sebesar $60.2 \%$, sedangkan sisanya sebesar $39,8 \%$ diterangkan oleh variabel lain yang tidak diajukan dalam penelitian ini.

\section{Pembahasan}

Menurut Maslow, (2009) motivasi merupakan salah satu faktor penting untuk meningkatkan produktifitas kerja. Sementara menurut Prabundu (2004), pencapaian produktifitas kerja salah satu diantaranya dapat dipengaruhi oleh budaya organisasi, sedangkan menurut Balai Pengembangan Produktivitas Daerah (dalam Umar, 2001: 11), produktifitas kerja diantaranya ditentukan oleh motivasi dan budaya kerja. Dengan demikian ketiga faktor di atas memiliki keterkaitan satu sama lain, yang dapat disimpulkan bahwa faktor motivasi dan budaya organisasi merupakan faktor yang menentukan produktifitas kerja karyawan.

Untuk melihat sejauhmana keterkaitan ke-3 faktor di atas, penulis telah melakukan penelitian di PT Boogy Avindo, dengan melibatkan sebanyak 35 orang responden, yang memberikan informasi mengenai pengaruh dari variabel Motivasi dan Budaya Organisasi terhadap Produktifitas Kerja.

Dari tabel tersebut dapat diterangkan bahwa angka $\mathrm{R}$ square sebesar 0.602 yang artinya bahwa variasi dari variabel bebas yaitu Motivasi dan Budaya Organisasi dapat menerangkan variabel Produktifitas Kerja sebesar $60.2 \%$, sedangkan sisanya sebesar $39,8 \%$ diterangkan oleh variabel lain yang tidak diajukan dalam penelitian ini.

Dari tabel uji validitas dapat diketahui bahwa variabel Motivasi dan Budaya Organisasi serta Produktifitas Kerja mempunyai Koefisien Korelasi > 0.30, sehingga dapat dikatakan bahwa indikator pertanyaan yang digunakan dalam penelitian ini adalah valid.

Dari tabel uji reliabilitas dapat diketahui bahwa masing-masing variabel Motivasi dan Budaya Organisasi serta Produktifitas Kerja diperoleh nilai Cronbach Alpha $\geq 0,60$. Dengan demikian, maka hasil uji reabilitas terhadap keseluruhan variabel adalah reliabel.

Dari gambar grafik distribusi normalitas menunjukkan bahwa titik-titik menyebar di sekitar garis diagonal dan mengikuti arah garis 
diagonal. Dengan demikian menunjukan pola distribusi yang normal, maka model regresi memenuhi asumsi normalitas, selain itu dapat dilihat bahwa sisaan juga menyebar normal dari kurva setangkup yang terbentuk. Dari tabel multikolinearitas dapat diketahui bahwa nilai Variance Inflation Factor ( VIF ) dari masing masing variabel bebas lebih kecil dari angka 10, dan nilai tolerance lebih besar dari 0,1 . Sehingga dapat disimpulkan bahwa pada uji regresi tersebut tidak terdapat probem multikolinieritas, maka model yang ada layak untuk dipakai.

Dari gambar heteroskedastisitas terdeteksi titik-titik yang ada adalah menyebar, dan tidak membentuk pola tertentu, sehingga tidak terjadi heteroskedastisitas.

Dari uji t diketahui bahwa nilai t hitung $>$ $\mathrm{t}$ tabel dan tingkat signifikan $<0,05$ untuk kedua variabel yaitu Motivasi dan Budaya Organisasi. Sehingga dapat disimpulkan bahwa variabel Motivasi dan Budaya Organisasi secara parsial (sendiri-sendiri) juga berpengaruh terhadap Produktifitas Kerja.

Dari uji $\mathrm{F}$ juga di ketahui bahwa $\mathrm{F}$ hitung $>\mathrm{F}$ tabel dan tingkat signifikasi $<0,05$ sehingga dapat disimpulkan bahwa variabel Motivasi dan Budaya Organisasi secara bersama-sama berpengaruh terhadap Produktifitas Kerja.

Dari hasil di atas, secara umum dapat disimpulkan bahwa ternyata mahasiswa menilai cukup baik terhadap ekuitas merek, Budaya Organisasi dan Produktifitas Kerja, dimana nilai dalam skala likert yang ada menunjukkan besarannya masing-masing sebesar 3,84;3,65 dan 3,82 yang berada di kisaran nilai $3.00 \mathrm{~s} / \mathrm{d}$ 4.00 .

Dari data di atas jelaslah sudah bahwa peranan Motivasi dan Budaya Organisasi merupakan variable yang sangat strategis dan menentukan dalam mempengaruhi tingkat Produktifitas Kerja, karena maju mundurnya suatui Perusahaan ditentukan oleh Produktyifitas Kerja Karyawannya. Semakin tinggi Produktifitas Kerja, semakin besar pula peluang Perusahaan untuk eksis dan berkembang.

Kita menyadari bahwa produktifitas kerja merupakan factor yang menentukan eksisitensi perusahaan, karena kita mengetahui bahwa kehadiran persaingan perusahaan berjalan sangat ketat, sehinga disadari atau tidak, langsung maupun tidak langsung, produktifitas kerja akan menjadi faktor yang sangat menentukan dalam menentukan maju mundurnya suatu perusahaan.

Dengan demikian faktor produktifitas kerja tersebut haruslah disikapi dengan bijak oleh setiap perusahaan, jika perusahaan tersebut ingin tetap eksis, maju dan berkembang.

Kita mengetahui bahwa setiap perusahaan senantiasa berusaha semaksimal mungkin untuk tetap eksis dan berkembang. Berbagai upaya dilakukan, salah satu diantaranya adalah dengan meningkatkan produktifitas kerja karyawannya

Untuk meningkatkan produktifitas kerja tersebut dapat ditempuh dengan melalui pendekatan mpeningkatan motivasi dan perbaikan budaya kerja, sehingga dengan demikian diharapkan akan terbangun produktifitas kerja yang semakin meningkat, karena jika tidak maka perusahaan tersebut lambat laun akan melemah, kalah bersaing dan akhirnya hancur (tutup).

Sehingga dengan demikian kunci pengembangan pertusahaan, terletak pada produktifitas, dan Produktifitas dapat dibangun melalui penedekatan peningkatan motivasi kerja karyawan serta perbaikan kualitas budaya organisasi.

\section{Kesimpulan}

Berdasarkan hasil analisis data yang telah dilakukan terhadap seluruh data yang diperoleh, maka dapat diambil kesimpulan sebagai berikut : a). Motivasi secara parsial berpengaruh positif terhadap Produktifitas Kerja yang ditunjukkan oleh nilai $r$ sebesar 0.815 yang berarti hubungan diantara keduanya kuat; b). Budaya Organisasi secara parsial berpengaruh positif terhadap Produktifitas Kerja ditunjukkan oleh nilai $r$ sebesar 0,747 yang berarti hubungan diantara keduanya kuat; c). Secara simultan variabel Motivasi dan Budaya Organisasi memiliki pengaruh yang signifikan terhadap Produktifitas Kerja yang ditunjukkan oleh nilai $\mathrm{r}$ sebesar 0,776 yang berarti hubungan diantara keduanya sangat kuat. Sedangkan nilai koefisien determinasi $\left(\mathrm{R}^{2}\right)$ adalah sebesar 0,602 yang berarti bahwa Motivasi bersama sama dengan Budaya Organisasi dapat menerangkan 
Arif Proyogo, Pengaruh Motivasi Dan Budaya Organisasi ...

variabel Produktifitas Kerja sebesar 60, $2 \%$, sedangkan sisanya sebesar $39,8 \%$ diterangkan oleh variabel lain.

\section{Saran}

Berdasarkan kesimpulan yang telah dikemukakan, maka diberikan beberapa saran yang diharapkan dapat meningkatkan Produktifitas Kerja PT Boogi Avindo. Adapun saran-saran yang diberikan bagi perusahaan adalah sebagai berikut: a). Berdasarkan data hasil questionare diperoleh indek Motivasi berdasarkan skala likert sebesar 3,84, yang berarti kualitas Motivasi dinilai sudah cukup baik, sehingga dengan demikian perlu dipertahankan kualitasnya, bahkan kalau perlu lebih ditingkatkan lagi dengan cara meningkatkan gaji, sarana kerja, jaminan keamana lingkungan kerja, dukungan kerjasama kerja karyawan, hubungan dengan perusahaan dan aktualisasi identitas diri; b) Berdasarkan data hasil questionare diperoleh indek Budaya Organisasi berdasarkan skala likert sebesar 3.65, yang berarti kualitas Budaya Organisasi dinilai sudah cukup baik, namun agar hasilnya lebih baik lagi, maka kualitas budaya organisasi perlu ditingkatkan lagi dengan cara meningkatkan iklim kerja inovasi karyawan, orientasi kerja kepada orang lain, orientasi hasil kerja tim, membangun nilai-nilai positif, pembinaan anggota serta menumbuhkan contoh teladan; c). Berdasarkan data hasil questionare diperoleh indek Produktifitas Kerja berdasarkan skala likert sebesar 3.65, yang berarti Produktifitas Kerja dinilai sudah cukup baik, namun agar hasilnya lebih baik lagi, maka perlu meningkatkan upaya-upaya Produktifitas Perusahaan melalui peningkatan hubungan dengan pimpinan perusahaan, hubungan dengan rekan kerja, koordinasi pekerjaaan, komunikasi antar bagian, tanggung jawab pekerjaan serta jumlah tenaga kerja.

\section{DAFTAR PUSTAKA}

Aditya Reza, Regina. (2010). Pengaruh Gaya Kepemimpinan, Motivasi, dan Disiplin Kerja terhadap Kinerja Karyawan PT. Sinar Santosa Perkasa Adi Cahyanto. 2009.
Arep, Ishak dan Hendri Tanjung. (2003). Manajemen Motivasi. Grasindo, Jakarta

Ekayadi, Septyaningsih. (2010). Pengaruh Motivasi dan Pengembangan Karir Terhadap Kepuasan Kerja Karyawan Pada PT. Rimbajatiraya Citrakarya. Universitas Gunadarma, Jakarta.

Ekayadi, Septyaningsih. (2010). Pengaruh Motivasi dan Pengembangan Karir Terhadap Kepuasan Kerja Karyawan Pada PT. Rimbajatiraya Citrakarya. Universitas Gunadarma, Jakarta.

Hasibuan. (2003b). Organisasi dan Motivasi. Bumi Aksara, Jakarta.

Hofstede, Geert, 1997, Culture's and Organization, New York, Washington D.C London, Me Craw-Hill, hal.9

Koesmono, H.Teman. (2005). Pengaruh Budaya kerja Terhadap Motivasi dan Kepuasan

Korter, Jhon P, and James L. Hesket, 1992, Corporate Culture and Performance, New York, Maxwell, Macmillan, Canada, Inc.

Kotter, J.P. Heskett S.L. 1997, Corporate Culture and Performance, Alih bahasa Benyamin Molan.

McNamara, Clayton, 1999, Organizational Culture, Oxford University Press, Oxford.

Moelyono, Djokosantoso, 2005. Cultured, Budaya Organisasi dalam Tantangan, Jakarta, PT Elex Media Komputindo.

Nining Fadliyah. 2003. Pengaruh Lingkungan Kerja Terhadap Produktivitas Kerja Karyawan PT. Fajar Mulia Pradipta, Surakarta. Surakarta : Universitas Muhammadiyah Malang.

Paul dan Kenneth H. Blanchard. 1995. Manajemen Perilaku Organisasi : Pendayagunaan Sumber Daya Manusia. Terjemahan Agus Dharma. Jakarta. Erlangga 
Majalah Ilmiah Ilmu Administrasi

ISSN 1411-0830

Pengaruh Disiplin Kerja Terhadap Produktivitas Kerja Karyawan Bagian Produksi Pada PT. Karet Ngagel Surabaya Wira Jatim. Surabaya : UNITOMO.Banjarnegara. Universitas Diponegoro, Semarang.

Pheysey, Diana C., 1993, Organization Cultures : Types and Transformations, Routledge, New York.

Robbins. (2006). Organizational Behavior. Tenth Edition. Edisi Bahasa Indonesia. PT Indeks Kelompok Gramedia, Jakarta.

Siagian. (2002). Kiat - Kiat Meningkatkan Produktivitas Kerja. Rineka Cipta,Jakarta.

Tika, Moh. Pabundu, 2006. Budaya Organisasi dan Peningkatan Kinerja Perusahaan. Jakarta, Bumi Aksara.

Triguno. 1997. Budaya Kerja, Menciptakan Lingkungan yang Kondusif untuk Meningkatkan Produktivitas Kerja. PT. Golden Teravon Press. Jakarta

Zulkarnain Saman. 2006. Pengaruh Motivasi dan Disiplin Kerja Terhadap Produktivitas dalam rangka Peningkatan Kinerja Pegawai Pada Dinas Tata Ruang dan Permukiman Propinsi Jawa Barat. Bandung : STIE Pasundan. 